\title{
Study and Rate Analysis of Escalation in Construction industry
}

\author{
K. Vamsidhar ${ }^{1}$, D. A. Eshwarswaroop ${ }^{2}$, K. Ayyappapreamkrishna ${ }^{3}$, \\ R. Gopinath ${ }^{4}$ \\ ${ }^{1,2,3}$ Final Year Student, Department of Civil Engineering , Sathyabama University, Chennai, India. \\ ${ }^{4}$ Assistant Professor, Department of Civil Engineering, Sathyabama University, Chennai, India.
}

\begin{abstract}
The project is said to be successful when it is completed in desired time and cost. The construction delays are common problems in private residential projects in Chennai city. This problem occurs frequently during life time leading to dispute and litigations. Therefore it is essential to study and analyse causes of construction delay. The construction industry is large, volatile and requires tremendous capital outlays. Delay of the project is a main factor and major cause of construction claims. There is an acute necessity for a detailed investigation to identify the delay factors and choose correct actions to minimize the adverse effect of delay on time, within cost and for high quality output
\end{abstract}

\section{General}

The construction industry has a major role in the development of the Indian economy. This industry consumes 40 to $50 \%$ of the national five year plan outlay and contributes $20 \%$ of gross domestic product. Medium to large construction projects take over a year for completion and the cost of materials and labour often increase, which leads to major problems in administration of the contract.

Over the past few years the construction industry has been facing several problems due to rapid increase in the price of construction materials, labour, interest charges and equipment cost. Rate escalation is defined as changes in the cost or price of specific goods or services in a given economy over a period. This is a similar to the concepts of inflation and deflation except that escalation is specific to an item or class of items, it is often not primarily driven by changes in the money supply, and it tends to be less sustained.

While escalation includes general inflation related to the money supply, it is also driven by changes in technology, practices, and particularly supply and demand imbalances that are specific to a good or service in a given economy. For example, while general inflation in the US was less than 5\% in the 2003-2007 time period, steel prices increased by over $50 \%$ because of supply-demand imbalance. Cost escalation may contribute to a project cost overrun. In particular, this increase has been a major problem to the construction industry. In order to find out the percentage increase in cost of construction, a study and analysis has been done in this project

\section{Problems And Issues Due To Rate Escalation}

Price escalations have been affecting the construction industry during the last year causing many problems and many developers to rethink projects. Price escalation produces delays in construction projects, reduced scope projects or projects being cancelled. Escalation clauses could also impact public projects adversely due to the fact that prices being submitted are not being guaranteed during long period of time. In the past, general contractors were able to hold subcontractors and suppliers to their quotes for 60 days, 90 days or 120 days. Because of escalation fears, owners are finding fewer bidders for their projects, some projects need to find alternatives funding sources or canceling the project if additional money is not available. Contractor and supplier fears regarding potential, future price escalation, and the absence of price escalation clauses in most construction contracts, often leads to higher contract prices and larger project costs.

\subsection{SCOPE}

Construction includes building and civil engineering projects including work by contractors, by individual, by public sector direct labor or own account organizations and by construction units in commercial or industrial organizations that are recorded to other industries.

The definition of construction output may include professional services such as designers, planners, managers etc and it may include some but not necessarily all informal construction activity.

\subsection{OBJECTIVE}

> The objective of the proposed work is to compare the cost of construction such as building materials, labours and equipments for past six years from the year 2008 to 2013.

$>$ To find out various parameters that influences increase in the cost of construction. 
To forecast the percentage increase in cost of construction for the next three years 2014, 2015 and 2016.

$>$ To create a model that guides planners for quoting long term projects.

\section{Scheme Of Work}

Below given fig 2.1 represents the scheme of work followed in the project.

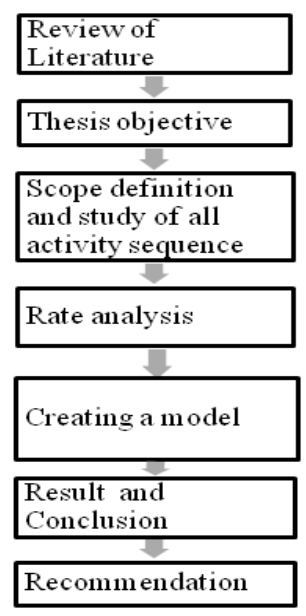

Fig 2.1 Methodology

Construction can be subdivided into new work and work to existing buildings and the latter can be subdivided into refurbishment and improvement and repair and maintenance

\subsection{Methods Of Forecasting Factor}

Construction cost indices have been used to measure the cost trends in the construction industry. Estimating the increase in price over the long term is almost impossible because of the many uncertainties beyond the control of all parties. The same is true of long term construction projects with multiyear schedules and start dates in the future. Despite this difficulty, the owners of large long-term projects need to come up with the estimated cost of these projects. The more prudent way to approach these problems is to calculate a range of possible costs rather than a single figure. Forecasting methods for escalation factors can be grouped into two major categories:

The last condition implies that some of the past pattern will continue into the future. This is an underlying premise of all the quantitative and many qualitative forecasting methods. Quantitative methods can be divided into two major categories: statistical and causal methods. Statistical methods utilize time-series analysis and curve fitting methods to forecast the variable in the future.

$\mathrm{n}$ the other hand, causal methods are developed assuming that the variable to be forecasted presents an explanatory or causal relationship with one or more independent variables.

\subsubsection{Simple average and exponential smoothing}

Examples of statistical methods consist of simple average and exponential smoothing. The method of simple average is basically to take average of all observed data as the forecast. The simple average is suitable for data that fluctuate around a constant or have a slowly changing level and do not have a trend or seasonal effects. The fundamental principle of the exponential smoothing is that the values of the variable in the latest periods have more impact on the forecast and therefore should be given more weight. This method implies that as historical data get older, their weight will decrease exponentially. Usually, it is a poor model for medium or long term forecast. Forecasts can be thrown into great error because of large random fluctuation in recent periods.

\subsubsection{Box-jenkins approach}

Other more complicated statistical forecasting methods are sometimes used also, but rarely in construction. For example, methods based on auto regressive integrated moving average ARIMA models are available; however their use has been limited. The time series analysis, forecasting, and control with the ARIMA model have come to be known as Box-Jenkins methodology. Despite Box-Jenkins promising results and power, forecasters and decision makers seldom use this method because it is complicated. It is best suited to short-term forecast, such as daily, weekly, or monthly and it require a large amount of data. 


\subsubsection{Reregression}

Regression methods are any modeling of a forecast variable $\mathrm{Y}$ as a function of a set of explanatory variables X1-Xk. The regression method's accuracy depends upon a consistent relationship with the independent variables. In regression methods, an accurate estimate of the independent variables is crucial. Multiple regression methods very often require a large amount of data.

\subsubsection{Neural networks}

Neural networks are part of the causal or explanatory methods. Neural networks are fundamentally based on simple mathematical models of the way the human brain is believed to work. They are distinguished for providing a nonlinear forecasting method when they are applied to time series. The use of neural networks for modeling cost escalation in construction has been limited. Hanna and Chao presented a neural network model as an alternative approach to forecast cost escalation in construction.

\subsubsection{Qualitative methods}

Qualitative forecasting methods, in contrast with quantitative methods, do not require data in the same way. The inputs required depend on the specific method and are in essence the product of judgment and accumulated knowledge. They can be used separately but are more often used in conjunction with quantitative methods. Qualitative methods are also called subjective methods Blair and judgmental methods.

\subsubsection{Surveys}

Surveys of expectation are one method of forecasting escalation. Surveys have proved to be less expensive, very accessible, and perform as well as many economic models. Several surveys of expected escalation are available today. Two of the most easily accessible and longest-standing surveys are the Livingston survey of professional economists and the Michigan survey of households. These are not aimed at construction costs but the methodology can be tailored for construction industry. One can conduct a survey of expectation of construction professionals to forecast escalation in this industry. Because the survey information is virtually costless, a cost benefit analysis suggests that many firms might agree to use surveys to assess the future cost of escalation.

\subsection{Steps Involved In Methodology}

The above said methodology is to study, analyze and compare the rate of construction materials cost, labour cost, equipment cost for past six years. The detailed methodology can be explained as follows:

Step1: Study of literature is available in the form of books, journals to get proper understanding of the issue.

Step2: List out various books required for reference and related topic, collect literatures and carry out desk research.

Step3: Making a list of companies and hardware shops to approach.

Step4: Collection of bill of quantity for residential apartment from a construction company.

Step5: Validation of bill of quantity

Step6: Collected labour rates, material rate and equipment rate from a construction company and hardware's for entire structure.

Step7: Rate analysis is done

Step8: Preparation of bill of quantity with rates obtained.

Step9: Comparison of bill of quantity for past six years from 2008 to 2013.

Step10: Forecasting is done for next three years 2014, 2015 and 2016 using Microsoft excel.

Step11: Results, discussion and conclusion.

\subsection{General}

\section{Data Collection}

Data Collection is an important aspect of any type of research study. Inaccurate data collection can impact the results of a study and ultimately lead to invalid results. Data are primarily collected to provide information regarding a specific topic. At the one end of this continuum are quantitative methods and at the other end of the continuum are qualitative methods for data collection.

\subsection{Impact Of Inflation On Construction}

Due to increase in the cost of fuel, transportation, electricity, lending rate for various small scale industrial sectors, power cuts, and value added taxes and service taxes the overall cost of Construction has escalated, which has been studied in detail hereafter. 


\subsection{FACTORS INFLUENCING MARKET PRICE}

The various important factors which influences increase in the cost of Construction materials in Tamil Nadu are,

- Increase in transportation charges

- Increase in electricity charges

- Increase in labour cost charges

- Increase in equipment charges

- Increase in material charges

- Increase in Lending rate for various SSI sector.

- Power cuts

- Increase in VAT and Service taxes

- Increase in demand for residential building

\subsection{Materials And Products}

These are basic inputs and include simple materials such as cement, sand, and reinforcement steel as well as manufactured products such as concrete, fired clay products and plywood. This category may also include composite products such as window units comprising frames, glazing and fittings such as hinges and locks and products like these include not only basic material inputs but other manufactured products and the labor involved in assembling them.

A particular problem area in international comparisons is materials, products and assemblies for mechanical including, lifts and heating, ventilating and air conditioning installations and electrical and other power and utility installations. In developed countries, mechanical and electrical installations can represent one third or more of the total cost of construction, particularly building, projects so they cannot be ignored. The Bar chart and tabular column of comparison of bulk construction materials and comparison of composite construction materials is represented.

\subsection{Bulk Construction Materials}

Table 3.1 Comparison tabular column of Bulk construction material

\begin{tabular}{|c|c|c|c|c|c|c|c|c|}
\hline $\begin{array}{c}\text { Item } \\
\text { no }\end{array}$ & Item description & Unit & $\begin{array}{c}\text { Basic } \\
\text { rate }\end{array}$ & & & & & \\
\hline & & & 2008 & 2009 & 2010 & 2011 & 2012 & 2013 \\
\hline 1 & Cement & Bag & 215.00 & 220.00 & 225.00 & 260.00 & 280.00 & 300.00 \\
\hline 2 & Reinforcement steel & $\mathrm{Kg}$ & 26.00 & 29.00 & 32.00 & 38.00 & 45.00 & 62.00 \\
\hline 3 & Structural steel & $\mathrm{Kg}$ & 39.00 & 42.00 & 38.00 & 45.00 & 55.00 & 85.00 \\
\hline 4 & River Sand & $\mathrm{Cft}$ & 18.00 & 22.00 & 22.00 & 26.00 & 40.00 & 42.00 \\
\hline 5 & 40mm aggregate & $\mathrm{Cft}$ & 17.00 & 19.00 & 18.00 & 20.00 & 22.00 & 30.00 \\
\hline 6 & $20 \mathrm{~mm}$ aggregate & $\mathrm{Cft}$ & 18.00 & 20.00 & 18.00 & 21.00 & 24.00 & 32.00 \\
\hline 7 & $12 \mathrm{~mm}$ aggregate & $\mathrm{Cft}$ & 14.00 & 17.00 & 17.00 & 20.00 & 21.00 & 27.00 \\
\hline 8 & $6 \mathrm{~mm}$ aggregate & $\mathrm{Cft}$ & 10.00 & 12.00 & 12.00 & 13.00 & 13.00 & 25.00 \\
\hline 9 & Quarry Dust & $\mathrm{Cft}$ & 6.00 & 8.00 & 10.00 & 10.00 & 12.00 & 22.00 \\
\hline 10 & Bricks & No & 3.25 & 3.25 & 4.00 & 4.00 & 6.50 & 7.00 \\
\hline 11 & Fly ash bricks 9"x4"x3" & No & 2.75 & 2.75 & 3.50 & 4.50 & 5.50 & 6.00 \\
\hline 12 & Fly ash bricks 9"x4"x4" & No & 3.50 & 3.50 & 4.50 & 5.00 & 6.00 & 6.50 \\
\hline 13 & Fly ash bricks 9"x9"x4" & No & 14.00 & 14.50 & 16.00 & 18.00 & 20.00 & 20.00 \\
\hline 14 & RR Stone & No & 9.00 & 10.00 & 11.50 & 11.50 & 12.00 & 12.00 \\
\hline 15 & Soling Stone & $\mathrm{Cft}$ & 13.50 & 14.00 & 16.00 & 16.00 & 20.00 & 20.00 \\
\hline 16 & Solid Block, 200mm thick & No & 23.00 & 25.00 & 26.00 & 30.00 & 30.00 & 31.00 \\
\hline 17 & Solid Block, 150mm thick & No & 20.00 & 21.00 & 24.00 & 28.00 & 28.00 & 29.00 \\
\hline 18 & Solid Block, 100mm thick & No & 11.50 & 13.00 & 16.00 & 18.00 & 25.00 & 26.00 \\
\hline 19 & Earth brought from Outside & $\mathrm{Cft}$ & 3.50 & 4.00 & 4.50 & 6.00 & 7.00 & 7.00 \\
\hline 20 & Gravel & $\mathrm{Cft}$ & 4.00 & 5.00 & 6.50 & 7.00 & 8.00 & 8.00 \\
\hline 21 & Brick aggregate & $\mathrm{Cft}$ & 22.00 & 24.00 & 28.00 & 30.00 & 35.00 & 36.00 \\
\hline 22 & Plasticizer & $\mathrm{Kg}$ & 62.00 & 68.00 & 70.00 & 76.00 & 80.00 & 80.00 \\
\hline 23 & Bitumen 80/100 & $\mathrm{Kg}$ & 32.00 & 36.00 & 38.00 & 40.00 & 41.00 & 45.00 \\
\hline
\end{tabular}


Graph 3.1 hike in bulk construction materials cost
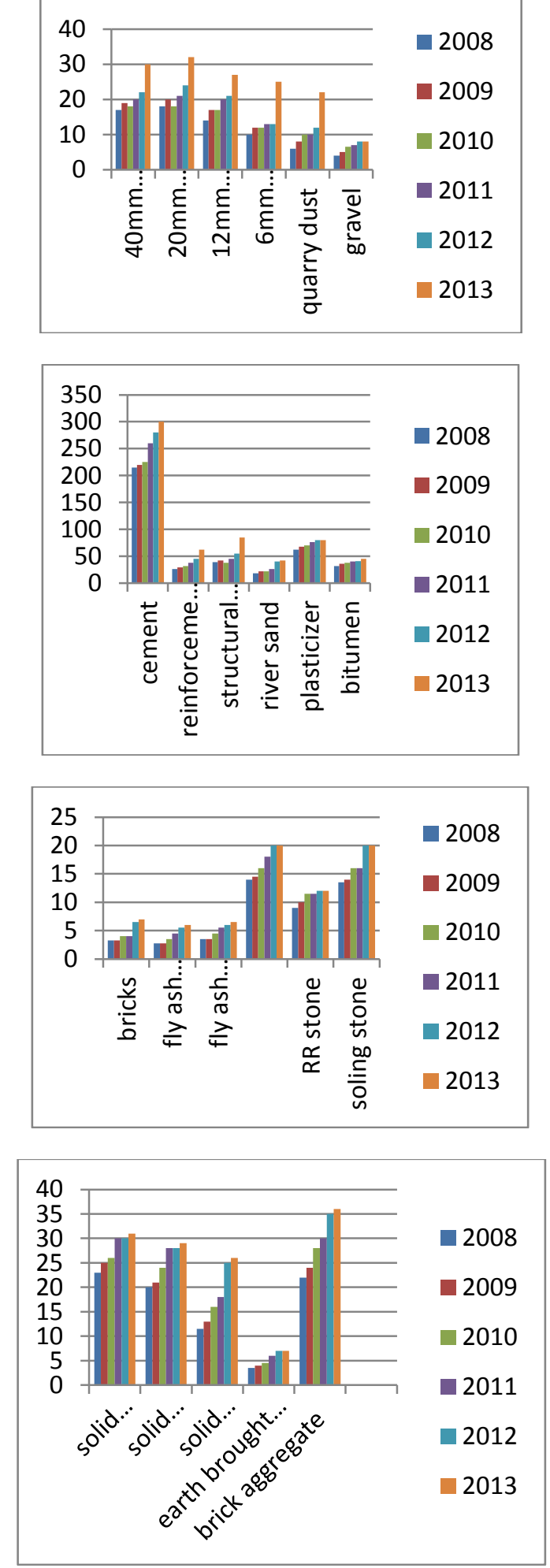

Graph 3.2 hike in bulk construction materials cost

The increase in bulk construction material cost has escalated by $84 \%$ during the period $2008-2013$ is represented in graph 3.1 and 3.2. 


\subsection{Composite Materials}

Table 3.2 Comparison tabular column of composite materials

\begin{tabular}{|c|c|c|c|c|c|c|c|c|}
\hline \multicolumn{9}{|c|}{ JOINERY WORK } \\
\hline \multirow{2}{*}{$\begin{array}{c}\text { Item } \\
\text { no }\end{array}$} & \multirow{2}{*}{ Item description } & \multirow[t]{2}{*}{ Unit } & \multicolumn{6}{|c|}{ Basic rate } \\
\hline & & & 2008 & 2009 & 2010 & 2011 & 2012 & 2013 \\
\hline 1 & 1st class Padauk wood & $\mathrm{Cft}$ & 2020 & 2040 & 2210 & 2340 & 2464 & 2450 \\
\hline 2 & 2nd class teak wood & $\mathrm{Cft}$ & 2250 & 2300 & 2450 & 2600 & 2800 & 2800 \\
\hline 3 & 1st class Burma Teak wood & $\mathrm{Cft}$ & 3300 & 3400 & 3600 & 3700 & 4000 & 4000 \\
\hline 4 & $\begin{array}{l}\text { Skin moulded door shutter }-35 \mathrm{~mm} \\
\text { tk. made with high density } \\
\text { Fiberboards(HDF) and Skin } \\
\text { (Boiling Water Proof) facing, solid } \\
\text { timber core and heavy duty - } 6 \mathrm{~mm} \\
\text { tk. Teak wood lipping. }\end{array}$ & Sqft & 110 & 115 & 120 & 130 & 160 & 170 \\
\hline 5 & $\begin{array}{l}\text { Factory made flush shutter - solid } \\
\text { core type - both side commercial } \\
\text { ply veneered IS: } 2202 \text { Part I } \\
\text { (1999) and ISI with black board } \\
\text { core and } 12 \mathrm{~mm} \text { tk. external teak } \\
\text { wood lipping (For Internal and } \\
\text { Toi. Doors) }\end{array}$ & Sqft & 88 & 92 & 100 & 105 & 155 & 180 \\
\hline 6 & Labour charges for wood work & Sqft & 55 & 57 & 60 & 65 & 70 & 80 \\
\hline 7 & $\begin{array}{l}\text { SS Butt hinges IS: } 12817 \text { with SS } \\
\text { screws }(125 \times 64 \times 1.9 \mathrm{~mm})\end{array}$ & Each & 114 & 120 & 133 & 140 & 140 & 160 \\
\hline 8 & $\begin{array}{l}\text { Brass handle - 125mm size - IS } \\
3843-1995)\end{array}$ & Each & 210 & 215 & 230 & 250 & 250 & 300 \\
\hline 9 & $\begin{array}{l}\text { Brass hanging type floor door } \\
\text { stopper }(0.357 \mathrm{Kg})\end{array}$ & Each & 158 & 165 & 172 & 185 & 190 & 210 \\
\hline 10 & $\begin{array}{l}\text { Brass tower bolt } 250 \times 10 \mathrm{~mm} \text { (IS: } \\
\text { 204-1992) - Barrel type. }\end{array}$ & Each & 187 & 195 & 200 & 210 & 218 & 240 \\
\hline 11 & $\begin{array}{l}\text { Aluminum handle }-100 \mathrm{~mm} \text { with } \\
\text { screws }\end{array}$ & Each & 54 & 58 & 62 & 66 & 70 & 85 \\
\hline 12 & $\begin{array}{l}\text { Aluminum tower bolt } 250 \times 10 \mathrm{~mm}- \\
\text { ISI - (Anodic coating not less than } \\
\text { grade AC }\end{array}$ & Each & 66 & 70 & 72 & 80 & 86 & 95 \\
\hline 13 & Aluminum bolt - 150x10mm & Each & 43 & 45 & 48 & 55 & 58 & 60 \\
\hline 14 & $\begin{array}{l}\text { Aluminum tower bolt - } \\
100 \times 10 \mathrm{~mm}\end{array}$ & Each & 37 & 39 & 42 & 45 & 48 & 52 \\
\hline 15 & $\begin{array}{l}\text { Aluminum sliding door bolt } \\
300 \times 16 \mathrm{~mm} \text { ISI - } \text { (IS:7534-1985) } \\
\text { (Anodic coating not less than } \\
\text { grade AC 10) }\end{array}$ & Each & 100 & 104 & 115 & 120 & 125 & 140 \\
\hline 16 & $\begin{array}{l}\text { Aluminum hanging type floor } \\
\text { door stopper. }\end{array}$ & Each & 18 & 18 & 20 & 20 & 25 & 25 \\
\hline 17 & $\begin{array}{l}\text { Brass Mortise latch and lock - } \\
\text { Vertical type - size } 100 \mathrm{~mm} \text { - clear } \\
\text { depth of body not more than } \\
150 \mathrm{~mm} \text { - Latch bolt of size } \\
12 \mathrm{mmx} 16 \mathrm{~mm} \text {. }\end{array}$ & Each & 1337 & 1350 & 1400 & 1400 & 2360 & 2450 \\
\hline 18 & $\begin{array}{l}\text { 100mm MS Mortise latch of } \\
\text { vertical lock - two levers - Latch } \\
\text { bolt of size } 8 \times 25 \mathrm{~mm} \text { (IS 5930- } \\
1970 \text { ) }\end{array}$ & Each & 965 & 970 & 1000 & 1015 & 1530 & 1600 \\
\hline 19 & $\begin{array}{l}\text { Chain link - solid brass (Antique } \\
\text { metallic finish round type } 6 " \text { to } 8 " \\
\text { length and dia } 8 \mathrm{~mm}\end{array}$ & Each & 153 & 158 & 163 & 170 & 175 & 190 \\
\hline 20 & $\begin{array}{l}\text { Brass Antique door viewer made } \\
\text { of solid brass \& lenses (Covering } \\
\left.\text { angle of } 180^{*}\right)-25 \mathrm{~mm} \text { dia. }\end{array}$ & Each & 120 & 124 & 130 & 136 & 142 & 150 \\
\hline 21 & $\begin{array}{l}\text { Rubber buffer - } 50 \mathrm{~mm} \text { dia - } \\
65 \mathrm{~mm} \text { long. }\end{array}$ & Each & 22 & 22 & 24 & 24 & 26 & 30 \\
\hline
\end{tabular}

Table 3.2 Comparison tabular column of composite materials

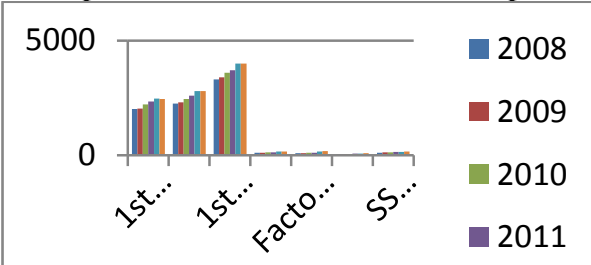




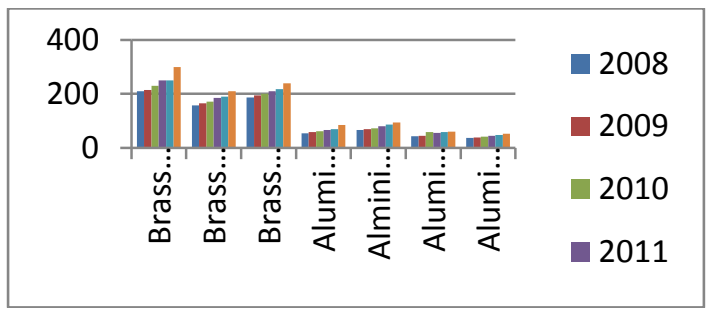

Graph 3.3 Hike in composite materials cost

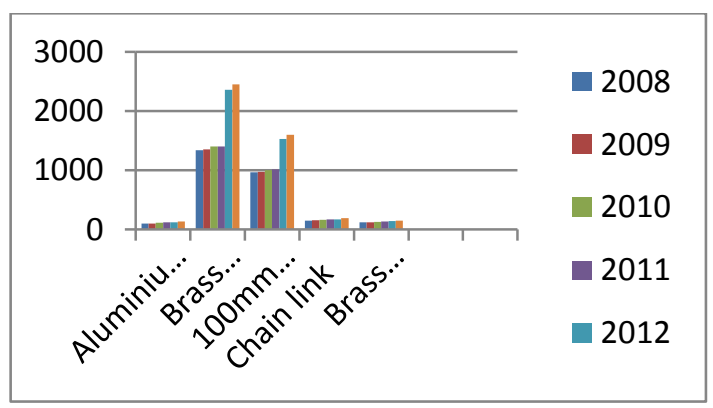

Graph 3.4 Hike in composite materials cost

The increase in composite material cost has escalated by $52 \%$ during the period $2008-2013$ is represented in graph 3.3 and 3.4 .

\subsection{Construction Equipment Hire}

- Construction equipment includes a range of items from tower cranes and bulldozers to smaller hand operated items.

- Equipment can be owned by the main contractor, hired as required or included in sub contractor prices.

- If it is owned by the main contractor then the costs of use are generally calculated as a periodic rate such as daily, weekly etc based on the purchase cost, ownership costs and running costs over the life of the item.

- Rates may include the cost of specialist operators, transport, establishment on site and return to depot costs.

- The rent for hiring each construction equipment from the year 2008 to 2013 is shown in table 3.3 and Graph 3.5

Table 3.3 comparison tabular column for hiring equipments

\begin{tabular}{|c|c|c|c|c|c|c|c|c|}
\hline \multicolumn{9}{|c|}{ EQUIPMENT RENT } \\
\hline \multirow{2}{*}{$\begin{array}{l}\text { Ite } \\
\text { no }\end{array}$} & \multirow{2}{*}{$\begin{array}{c}\begin{array}{c}\text { Item } \\
\text { description }\end{array} \\
\end{array}$} & \multirow{2}{*}{ Unit } & \multicolumn{6}{|c|}{ Basic rate } \\
\hline & & & 2008 & 2009 & 2010 & 2011 & 2012 & 2013 \\
\hline 1 & $\begin{array}{l}\text { Road roller } 8 \\
\text { to } \\
\text { 12tonne } \\
\text { capacity }\end{array}$ & $\begin{array}{l}\text { Per } \\
\text { hour }\end{array}$ & 680 & 740 & 810 & 850 & 900 & 1100 \\
\hline 2 & JCB & $\begin{array}{c}\text { Per } \\
\text { hour }\end{array}$ & 460 & 505 & 565 & 600 & 650 & 850 \\
\hline 3 & Bobcats & $\begin{array}{c}\text { Per } \\
\text { hour }\end{array}$ & 235 & 260 & 294 & 300 & 300 & 350 \\
\hline 4 & Forklifts & $\begin{array}{c}\text { Per } \\
\text { hour }\end{array}$ & 220 & 250 & 280 & 300 & 350 & 400 \\
\hline 5 & $\begin{array}{l}\text { Dewatering } \\
\text { pumps }\end{array}$ & $\begin{array}{c}\text { Per } \\
\text { hour }\end{array}$ & 285 & 305 & 345 & 370 & 400 & 500 \\
\hline 6 & Excavators & $\begin{array}{c}\text { Per } \\
\text { hour }\end{array}$ & 1220 & 1335 & 1490 & 1600 & 1800 & 2000 \\
\hline 7 & $\begin{array}{l}\text { Concrete } \\
\text { Mixers }\end{array}$ & $\begin{array}{c}\text { Per } \\
\text { hour }\end{array}$ & 75 & 90 & 105 & 120 & 150 & 190 \\
\hline 8 & Truck & $\begin{array}{l}\text { Per } \\
\text { hour }\end{array}$ & 210 & 240 & 260 & 270 & 300 & 375 \\
\hline
\end{tabular}




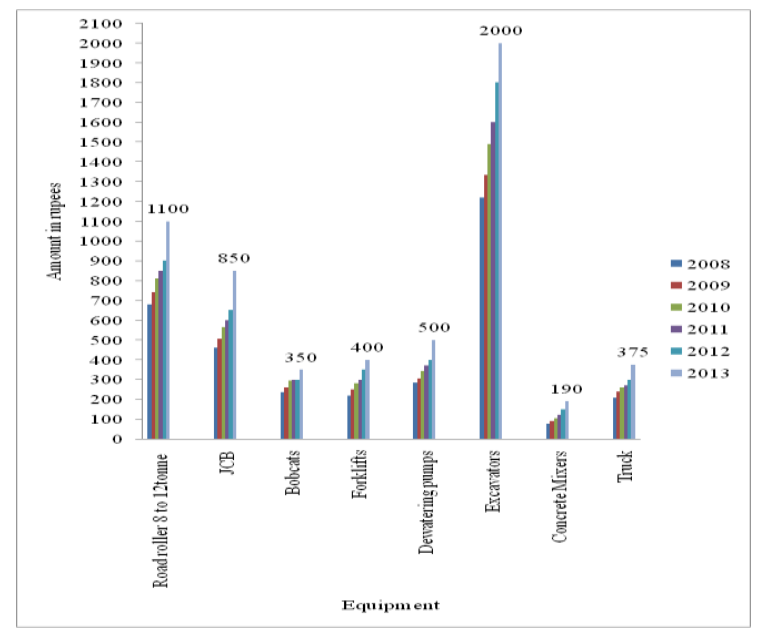

Graph 3.5 Hike in construction equipment hire charges

The increase in hiring cost of construction equipment charges has escalated by $\mathbf{7 3 \%}$ during period 2008-2013 is represented in graph 3.5.

\subsection{Construction Labour}

- This includes various types and categories of labor and how labor is described may vary from location to location and even from project to project.

- It includes direct labours who are employed directly by the main contractor, and such labor may include skilled trade people and general semi skilled or unskilled people.

- It also includes supervisory staffs who are generally employed by the main contractor.

- Costs associated with supervisory staff such as site foremen and site managers may be clearly specific while more senior staff costs may be embedded in company overheads so some care is required in measuring the costs of supervision in overall construction costs.

- The construction labour cost from the year 2008 to 2013 is shown in table 3.4 and graph 3.6.

Table 3.4 Comparison tabular column for construction labour

\begin{tabular}{|c|c|c|c|c|c|c|c|c|}
\hline \multirow{2}{*}{$\begin{array}{c}\text { Ite } \\
\text { m } \\
\text { no }\end{array}$} & \multirow[b]{2}{*}{ Item description } & \multirow{2}{*}{ Unit } & \multicolumn{6}{|c|}{ Basic rate } \\
\hline & & & 2008 & 2009 & 2010 & 2011 & 2012 & 2013 \\
\hline 1 & Mason & Per day & 220 & 250 & 300 & 400 & 500 & 600 \\
\hline 2 & Male helper & Per day & 140 & 170 & 200 & 300 & 350 & 350 \\
\hline 3 & Female helper & Per day & 100 & 130 & 150 & 200 & 250 & 300 \\
\hline 4 & curing Person & Per day & 100 & 130 & 150 & 200 & 250 & 300 \\
\hline 5 & Fitter Grade-I & Per day & 220 & 250 & 300 & 400 & 450 & 550 \\
\hline 6 & Fitter Grade - II & Per day & 180 & 200 & 225 & 250 & 300 & 400 \\
\hline 7 & Fitter (Helper) & Per day & 140 & 170 & 200 & 225 & 250 & 300 \\
\hline 8 & Carpenter 1st class & Per day & 220 & 250 & 300 & 400 & 450 & 550 \\
\hline 9 & $\begin{array}{l}\text { Carpenter 2nd } \\
\text { class }\end{array}$ & Per day & 180 & 200 & 225 & 300 & 350 & 450 \\
\hline 10 & $\begin{array}{l}\text { Carpenter } \\
\text { (Helper) }\end{array}$ & Per day & 140 & 170 & 200 & 225 & 250 & 300 \\
\hline 11 & $\begin{array}{l}\text { Painter / White } \\
\text { washer }\end{array}$ & Per day & 220 & 250 & 300 & 350 & 400 & 500 \\
\hline 12 & Painter ( Helper) & Per day & 140 & 200 & 225 & 250 & 300 & 350 \\
\hline 13 & Tile layer & Per day & 220 & 250 & 300 & 350 & 400 & 550 \\
\hline 14 & $\begin{array}{l}\text { Tiles layer } \\
\text { ( Helper) }\end{array}$ & Per day & 140 & 200 & 225 & 225 & 300 & 400 \\
\hline 15 & Glazier & Per day & 230 & 250 & 300 & 400 & 450 & 500 \\
\hline 16 & Glazier (Helper) & Per day & 150 & 200 & 225 & 250 & 250 & 300 \\
\hline 17 & Plumber & Per day & 220 & 250 & 300 & 400 & 450 & 550 \\
\hline 18 & $\begin{array}{l}\text { Electrician ( } \\
\text { Helper) }\end{array}$ & Per day & 220 & 200 & 225 & 250 & 250 & 350 \\
\hline 19 & $\begin{array}{l}\text { Mixer machine } \\
\text { operator }\end{array}$ & Per day & 140 & 170 & 200 & 250 & 350 & 400 \\
\hline 20 & Watchman & Per day & 150 & 170 & 200 & 250 & 250 & 300 \\
\hline
\end{tabular}




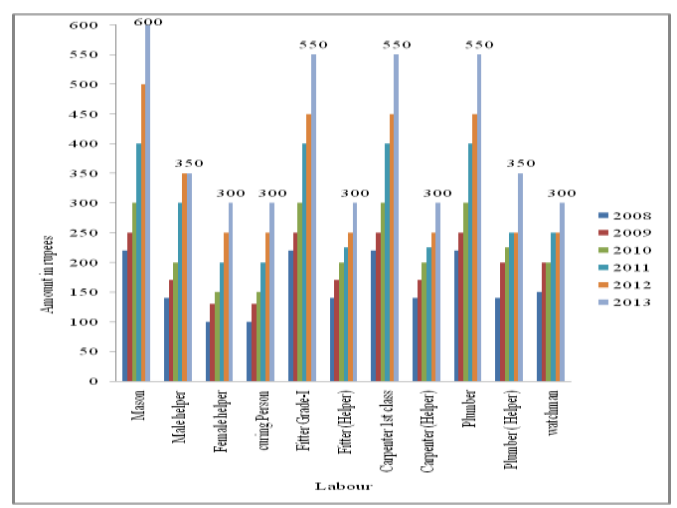

Graph 3.6 Hike in construction Labour cost

The increase in construction labour charges has escalated by $120 \%$ during the period 2008-2013 is represented in graph 3.6.

3.9 Increases In Fuel Cost

Table 3.5 Comparisons of petrol and diesel prices

\begin{tabular}{|c|c|c|}
\hline DATES & PETROL & DIESEL \\
\hline $02-22-08$ & 42.94 & 29.94 \\
\hline $07-06-08$ & $43 . .26$ & 30.23 \\
\hline $02-15-09$ & 45.52 & 31.76 \\
\hline $05-24-09$ & 45.56 & 31.80 \\
\hline $06-05-09$ & 50.56 & 34.80 \\
\hline $12-06-09$ & 45.62 & 32.86 \\
\hline $01-29-10$ & 40.62 & 30.86 \\
\hline $07-02-10$ & 44.63 & 32.87 \\
\hline $10-27-10$ & 44.72 & 32.92 \\
\hline $02-27-11$ & 47.43 & 35.47 \\
\hline $07-01-11$ & 51.45 & 40.12 \\
\hline $12-16-11$ & 55.87 & 40.12 \\
\hline $05-15-12$ & 63.37 & 41.12 \\
\hline $12-01-12$ & 68.55 & 46.32 \\
\hline $06-03-13$ & 75.40 & 49.68 \\
\hline $09-14-13$ & 73.52 & 55.37 \\
\hline
\end{tabular}

The cost of petrol and diesel prices from 2008 to 2013 is mentioned in table 3.5.

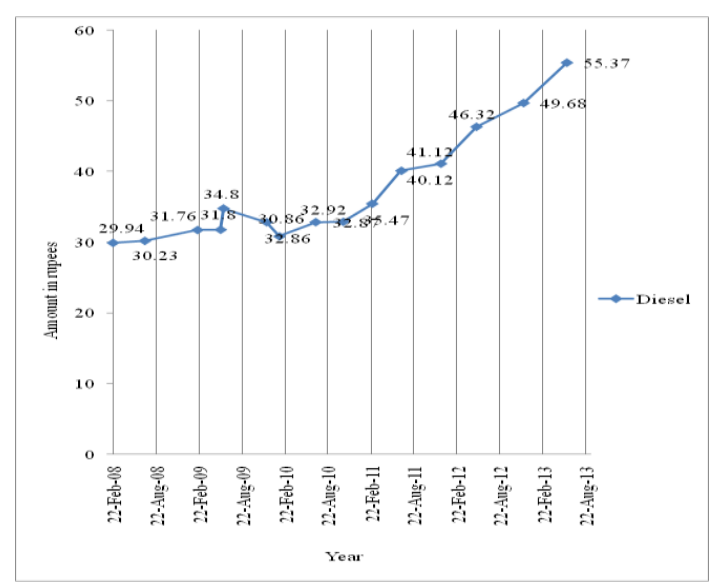

Graph 3.7 Hike in Diesel prices 
The diesel price has escalated by $\mathbf{8 4} \%$ during the period 2008-2013 is represented in graph 3.7.

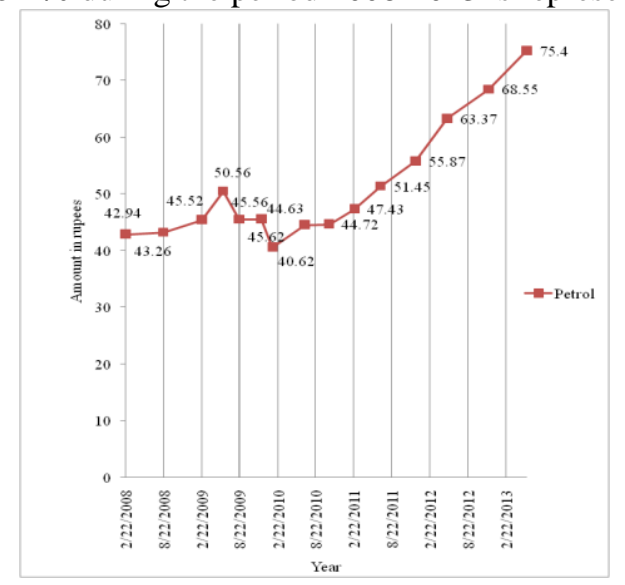

Graph 3.8 Hike in Petrol prices

The Petrol prices have escalated by $\mathbf{7 6} \%$ during the period 2008-2013 is represented in graph 3.8.

3.10 Increases In Transportation Cost

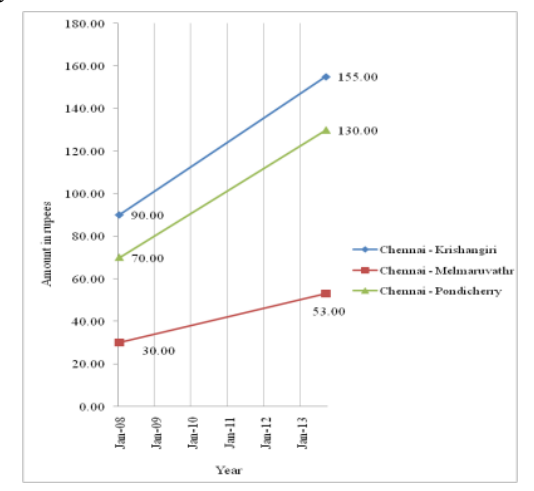

Graph 3.9 Hike in Transportation cost

The transportation cost has escalated by $\mathbf{7 2 \%}$ to $\mathbf{8 6 \%}$ during the period 2008-2013 due to increase in fuel cost is mentioned in graph $3.7 \& 3.8$.

3.11 Increases In Electricity Cost

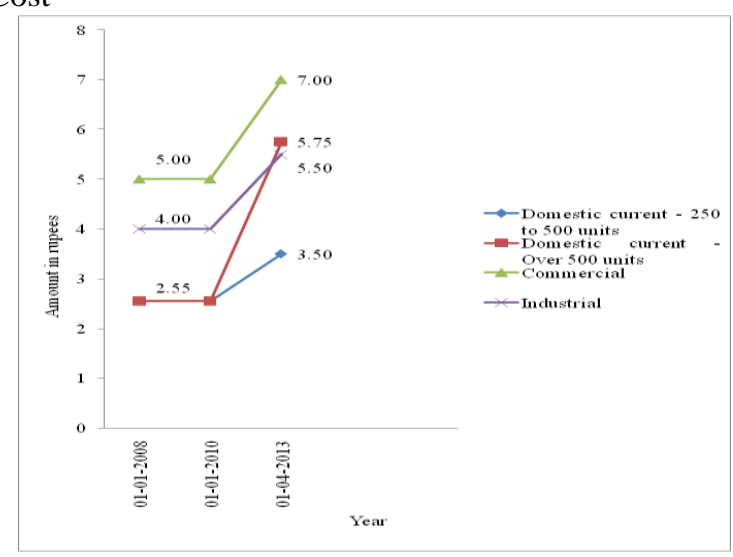

Graph 3.10 Hike in Electricity charges

The increase in electricity charges has escalated by $40 \%, 37.5 \%, \mathbf{1 2 5 . 4 9 \%}, \mathbf{3 7 . 2 5 \%}$ during the period2008-2013 is represented in graph 3.10. 


\section{Results And Discussion}

4.1 Comparison Of Bill Of Quantity

The detailed comparison bill of quantity for past six years from 2008 to 2013 is explained in annexure 1 ; the percentage increase in cost of construction is tabulated:

Table 4.1 Summary report of percentage increase in cost of construction

\begin{tabular}{|c|c|c|}
\hline Year & $\begin{array}{c}\text { Total cost of } \\
\text { project }\end{array}$ & $\begin{array}{c}\text { Increase } \\
\text { in \% }\end{array}$ \\
\hline 2008 & $3,11,81,134.00$ & -- \\
\hline 2009 & $3,44,88,341.00$ & $\mathbf{1 0 . 6 1 \%}$ \\
\hline 2010 & $3,75,90,988.00$ & $\mathbf{9 . 0 0 \%}$ \\
\hline 2011 & $4,25,56,169.00$ & $\mathbf{1 3 . 2 1 \%}$ \\
\hline 2012 & $4,81,97,263.00$ & $\mathbf{1 3 . 2 6 \%}$ \\
\hline 2013 & $5,31,30832.00$ & $\mathbf{1 0 . 2 4 \%}$ \\
\hline
\end{tabular}

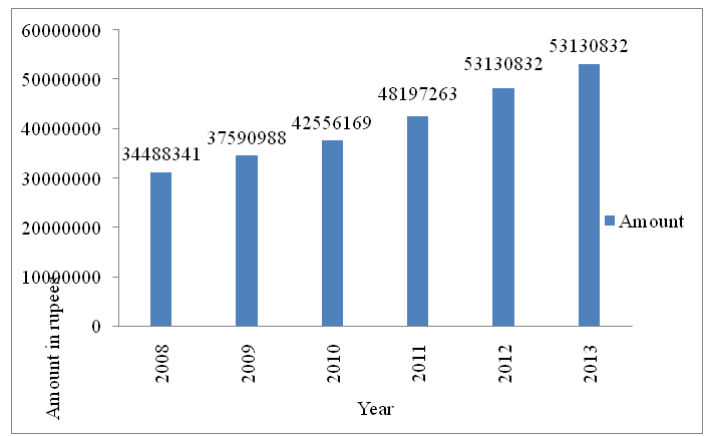

Graph 4.1 Percentage increase in cost of construction

The percentage increase in cost of construction is represented in graph 4.1. The construction cost form the year 2008-2009, 2009-2010, 2010-2011, 2011-2012,2012 -2013 has increased by $10.61 \%, 9.00 \%, 13.21 \%$, $13.26 \%, 10.24 \%$ respectively during this period is explained in annexure 1 .

\subsection{Forecasted Bill Of Quantity}

Using Microsoft excel software the construction prices are forecasted for next three years 2014, 2015 and 2016. The past data's collected for the analysis is given as input data's. The input variables are year and cost. The target variable is cost. Through forecasting technique using Microsoft excel is explained clearly in annexure 2 , the percentage increase in cost of construction for next three years from is tabulated:

Table 4.2 Summary report of forecasted cost

\begin{tabular}{|c|c|c|}
\hline Year & Total cost of project & Increase in \% \\
\hline 2014 & $5,94,28,448.00$ & $\mathbf{1 1 . 8 5 \%}$ \\
\hline 2015 & $6,64,69,342.00$ & $\mathbf{1 1 . 8 5 \%}$ \\
\hline 2016 & $7,44,08,271.00$ & $\mathbf{1 1 . 9 4 \%}$ \\
\hline
\end{tabular}

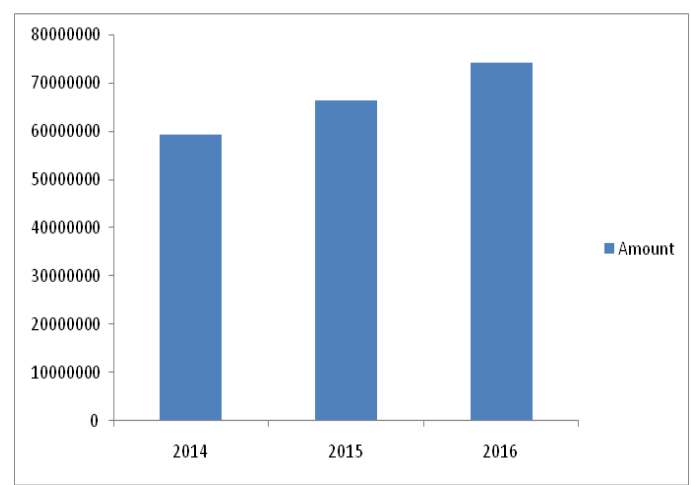

Graph 4.2 Forecasted cost 
The forecasted cost of construction from the year 2014 to 2016 is mentioned in graph 4.2. Through forecasting technique, it is found that cost escalation from 2013-2014, 2014-2015, and 2015-2016 will be increased by $11.85 \%, 11.85 \%$ and $11.94 \%$ is explained in annexure 2 .

\section{Conclusions}

1. The major parameters that influence the cost escalation in construction industry are steel, cement, aggregate, bricks, composite materials, equipments and labour costs are found.

2. From this case study, it is found that the price of steel, cement, aggregate, bricks, composite materials, equipments and labour cost were escalated by $138 \%, 36 \%, 60 \%, 115 \%, 55 \%, 63 \%, \& 140 \%$ for the past six years from 2008 to 2013 .

3. Labour cost plays a major role in cost escalation which has been escalated by $140 \%$ during this period.

4. The construction cost form the year 2008-2009, 2009-2010, 2010-2011, 2011-2012, 2012-2013 has increased by $10.61 \%, 9.00 \%, 13.21 \%, 13.26 \%, 10.24 \%$ respectively during this period is shown in annexure 1.

5. Forecasting has been done for next three years 2014, 2015 and 2016 using Microsoft excel.

6. Through forecasting technique, it is found that cost escalation from 2013-2014, 2014-2015, and 2015-2016 would be increased by $11.85 \%, 11.85 \%$ and $11.94 \%$ is shown in annexure 2 .

7. Forecasting has been done for 2014, 2015 and 2016 which will be useful for planning engineers for quoting new long term projects.

8. Labour cost plays a major role in cost escalation which has been escalated by $120 \%$, whereas equipment cost has escalated by $73 \%$ during last six years. So the use of equipments in construction industry can be maximized to reduce increase in construction cost.

\section{Recommendation}

Labour cost plays a major role in cost escalation which has been escalated by $120 \%$, whereas equipment cost has escalated by $73 \%$ during last six years. So the use of equipments in construction industry can be maximized to reduce increase in construction cost and avoid delaying of projects due to shortage of labours.

\section{References}

[1]. Abhishek Bhargava; Panagiotis Ch. Anastasopoulos. Journak of Construction Engineering and Management, Vol. 136, No. II. (Nov 2010), ' Three- stage Least Squares Analysis of Time and Cost Overruns in Construction Contracts',Pg no.20-25

[2]. Adnan Amin Alvanchi; SangHyun Lee, A.M.ASCE Vol. 138. No.1. (2012), 'Dynamics of working hours in construction',

[3]. Bee Hua Goh, Volume 40, (2005), Issue 2. 'The dynamic effects of the Asian financial crisis on construction demand and tender price levels in Singapore' Pg no. 23-26.

[4]. Brad W.Wambeke, 'Causes of Variation in Construction project task starting times and Duration' ASCE Vol 1(Sep 2011).

[5]. Byung Cheol Kim, A.M. Combination of Project cost Forecasts in Earned Value Management' ', ASCE Vol.2, (Nov 2011) and No.2.

[6]. ChangTaek Hyun, TaeHoon Hong, SoungMin, JunHyeok Yu, and SooBae, 'The Development of Probabilistic Time and Cost Data: Focus on

[7]. Khaled Nassar1 and Ossama Hosny. 'A Model for Assessing Maximum Overtime Rate in Labor Subcontracting Practices', Vol.2, (Jun 2012) No.2.

[8]. Mohammad A. Ammar 'Optimization of Project Time- Cost Trade off Problem with Discounted Cash Flows', journal of Construction Engineering \& management, Vol 137,(Jan 2011), No.1.

[9]. Skitmore, R.M. and Ng, S.T. 'Forecast Models for Actual Construction Time and Cost' Building and Environment 8(8) (2003):pp. 1075-1083.

[10]. Robert Lopez, Ph.D; and Peter E.D. Love, Ph.D, 'Design Error costs in Construction Projects', ASCE Vol 138, (May 2012), No.5.

[11]. Samuel Laryea and Will Hughes, (April 2011), 'Risk and price in the Bidding process of contractors', Vol.XVIII, (May 2012), No.1.

[12]. NarimahKasim. 'ICT Implementation for Materials Management in Construction Projects'Vol.1 (May 2011), No.1.

[13]. Paul H.K Ho. 'Forecasting Construction Manpower Demand by Gray Model', ASCE Vol.136,(Dec 2010), No.12.

[14]. field conditions and labor productivity’ Vol.1, (May 2011), No.1.

[15]. Dr.A.K.Garg, Arun Choudhary and Abhinandan Baishya, 'Time, Cost and Quality Control in Construction', Journal of Indian Buildings Congress, Vol XVIII (2011).

[16]. Enshassi, Khalid Al-Hallaq and Sherif Mohamed Journal of Construction in Developing Countries, Causes of Contractor's Business Failure in Developing Countries The Case of Palestine', Vol. 11, (2006), No. 2.

[17]. Fikiemo patience, 'Factors affecting cost of construction in Nigeria', Vol.2, (2008), No.2.

[18]. Hisham Said, S.M.ASCE: AND Khaled El-Rayes, 'Optimizing Material Procurement and Storage on Construction Sites', ASCE, and vol.137. (June 2011), No.6.

[19]. Khaled Nassar1 and Ossama Hosny. 'A Model for Assessing Maximum Overtime Rate in Labor Subcontracting Practices', Vol.2, (June 2011), No.2. 